\title{
Öğretim elemanlarının "topluluk karşısında konuşma becerileri” üzerine bir değerlendirme
}

\section{Kürşad KARA ${ }^{1}$}

\begin{abstract}
APA: Kara, K. (2020). Öğretim elemanlarının "topluluk karşısında konuşma becerileri” üzerine bir değerlendirme. RumeliDE Dil ve Edebiyat Araştırmaları Dergisi, (Ö7), 45-58. DOI: 10.29000/rumelide.808224.
\end{abstract}

Öz

Çalışmanın amacı, öğretim elemanlarının (Profesör, Doçent, Dr. Öğretim Üyesi) topluluk karşısında konuşma becerilerinin değerlendirilmesidir. Bu amaçla Türkiye'de bir üniversitede bahar ve güz eğitim öğretim süresince öğretim elemanlarının konferans, sempozyum, panel, forum gibi programlarda yaptıkları hazırlıklı konuşmalar değerlendirilmiştir. Çalışmada nitel araştırma desenlerinden durum çalışması yöntemi kullanılmıştır. Öğretim elemanlarının topluluk karşısında konuşma becerileri dinleyici gözünden derinlemesine değerlendirilmiştir. Değerlendirmeye 10 profesör, 3 doçent, 4 doktor öğretim üyesi katılmıştır. Katılımcıların tamamı Türk olup hepsinin anadilleri Türkçedir. Verilerin toplanmasında yapılandırılmamış gözlem formu kullanılmıştır. Bu süreçte; /ses, ton, vurgu, telaffuz yanlışları/, /konuşmanın şekilsel yönleri ile ilgili yanlışlar/, /konuşma esnasında yapılan teknik hatalar ve konuşmacıya dayalı yanlışlar/ başlıklarından oluşan çerçeve doğrultusunda veriler toplanmıştır. Topluluk karşısında yapılan konuşmada üzerinde durulması gereken önemli bölüm konuşma ile ilgili değerlendirme kısmıdır. Fakat yapılan hazırlıklı konuşmaların sonu daha çok soru cevaba ayrıldığı için konuşmacı özel ortamlarda konuşmasını değerlendirememekte, yaptığı hataları soramamaktadır. Bu nedenle farkında olunmadan yapılan her türlü konuşma kusuru konuşmacı tarafından öğrenilememekte ve bu kusurlar bir sonraki konuşmalara taşınmaktadır. Dinlemeyi çekilmez hâle getiren konuşma kusurlardan habersiz olan konuşmacı, zamanla istenmeyen ya da konuşmasına zorla katlanılan bir hatip durumuna düşebilmektedir. Bu bağlamda bu çalışma, öğretim elemanlarına topluluk karşısında yapmış oldukları konuşmalara dinleyici gözünden bakma imkânı sunmaktadır.

Anahtar kelimeler: Konuşma, konuşma becerisi, öğretim elemanı, diksiyon, konuşma kusuru

\section{Evaluate the speaking skills of the lecturers in front of the community}

\begin{abstract}
The study aims to evaluate the speaking skills of the lecturers (Professor, Associate Professor, Dr. Faculty Member) in front of the community. For this purpose, prepared speeches of instructors teaching at a university in Turkey at special occasions such as conferences, symposia, panel discussions, and forums during spring and fall semesters were evaluated. The Case study method, one of the qualitative research patterns, was used in the study. The speaking skills of the lecturers in front of the community were evaluated in depth through the eyes of the audience. 10 professors, 3 associate professors, 4 doctor lecturers participated in the evaluation. All the participants being Turkish, their mother tongue is Turkish as well. The unstructured observation form was used to collect the data. In this process, the data were collected in line with the framework such as /sound,
\end{abstract}

1 Dr. Öğr. Üyesi, Bayburt Üniversitesi, Eğitim Fakültesi, Türkçe ve Sosyal Bilimler Eğitimi Bölümü (Bayburt, Türkiye), kkara@bayburt.edu.tr, ORCID ID: 00oo-0002-8190-5180 [Makale kayıt tarihi: 22.05.2020-kabul tarihi: 20.10.2020; DOI: $10.29000 /$ rumelide.808224] 


\begin{abstract}
tone, accent, pronunciation mistakes /,/ mistakes in the formal aspects of speech /, / and technical errors during the speech and speaker-based mistakes/. The important part that should be emphasized in the speech made in front of the community is the evaluation part of the speech. However, since the end of the prepared speeches are mostly reserved for questions, the speakers cannot evaluate their speech in private environments and cannot ask the mistakes they made. For this reason, all kinds of speech defects not realized cannot be learned by the speaker and these defects are carried to the next speeches. The speaker, unaware of the speech imperfections that makes listening unbearable, may become an unwelcome orator or an orator who is barely put up with. In this context, this study provides the opportunity for the lecturers to look at the speeches they make in front of the audience from the audience's eyes.
\end{abstract}

Keywords: Speaking, speaking skill, lecturers, diction, speech defect

\title{
Giriş
}

Sosyal hayat içerisinde yaşama zorunluluğu olan insan, günlük hayatta yoğun olarak bir iletişim içerisinde yer alır. Bu iletişimde ya konuşan tarafta ya da dinleyen taraftadır. Konuşma sürecinde bir taraftan duygularını, düşüncelerini ifade eder, diğer taraftan anlaşılma kaygısı yaşar. Çünkü sağlıklı bir iletişimin gerçekleşmesi için mesajın alıcı tarafından da anlaşılması gerekmektedir. Burada en önemli pay kaynak kişiye, kaynak kişinin anlaşılır konuşma becerisine aittir.

Bireyler günlük hayat içerisinde her türlü ortamda konuşma becerilerini sergilerler. Konuşmanın temelindeki amaç duygu, düşünce ve dileklerimizi; görsel, işitsel öğeler aracılığı ile karşımızdakine iletmektir (Taşer, 2012: 27; Ünalan, 1999: 111). Çünkü konuşma, mutabık kalınan işaretlerin ve seslerin karşıdakinin zihninde anlam oluşturmasını, mesaja dönüşmesini sağlayan fiziksel ve zihinsel bir süreçtir. Bu süreç; zihnin söz kalıbına döktüğü ve oluşturduğu düşüncelerin, duyguların şekillendirilmesiyle gerçekleşir (Erdem, 2013: 416; Güneş, 2007: 95). Ayrıca konuşma; insanın, karşısındaki kişiyi ya da kişileri etkilemek amacıyla kasların hareket etmesinden doğan ses-ışık dalgalarının oluşturduğu psiko-fiziki de bir süreçtir. Bu tanıma göre; bir el hareketi, bir gülümseme, omuz silkme, kaş çatma, bir inilti, bir haykırış, söylenen bir söz, bir tümce, kısaca bunlardan biri yahut bunların bir bileşimini de konuşmak saymak gerekir (Taşer, 2012: 63). Duruş, bakış, jest ve mimikler; konuşmacı hakkında tahminler ve değerlendirmeler yapma firsatı vererek konuşmacı-dinleyici arasında olumlu ya da olumsuz bağ kurulmasını sağlar (Şahin ve Aydın, 2015: 226). Beden dili doğru ve yerinde kullanılırsa konuşmayı tamamlar ve konuşmanın daha açık ve anlaşılır bir hale gelmesini sağlar.

Söyleyenle dinleyen arasında gerçekleşen konuşma eylemi etki ve tepki sürecini içerir. Bu süreç etki (söyleme/sav), tepki (dinleme/karşı sav) ve etkileşim kavramlarıyla formüle edilebilmektedir ve konuşan-ileti-dinleyici-ortam şeklinde gerçekleşir (Taşer, 2012: 117). Konuşma eyleminin gerçekleşmesiyle etki süreci başlar. Bu etkinliğin temelinde bir amaç vardır. Amaçsız şekilde yapılan konuşmaların varlığı da söz konusudur lakin insanoğlu konuşmalarını genelde bir amaç doğrultusunda yapar. Amaçlarımızdaki farklılıklar yapılacak konuşmanın da türünü belirler.

Konuşma türleri; hazırlanma durumuna göre hazırlıksız (günlük) konuşma, hazırlıklı konuşma (konferans, münazara, sempozyum, panel, forum, açıkoturum, söylev, röportaj, görüşme, seminer, kongre, demeç vb.) olarak ikiye ayrılır. Çalışmada ele alınan hazırlıklı konuşmalar; yeri ve zamanı önceden belirlenerek farklı insan toplulukları karşısında yapılan konuşmalardır. Bu tür konuşmaların 
konusu hem konuşmacı hem de dinleyiciler tarafından bilinmektedir. Dinleyiciler, önceden belirlenmiş konular hakkında bilgi edinmek amacıyla konuşmacıyı dinlerler. Konuşmalar bir plan dâhilinde yapılır, bu sayede hem konuşmacının sunumu hem de dinleyicinin anlaması kolaylaşır (Temizyürek, Erdem ve Temizkan, 2016). Bu tarz konuşmalar, yazılı anlatımda olduğu gibi uzun ve ciddi bir hazırlık döneminden sonra gerçekleşir. Bu dönemde öncelikle konuşma metninin oluşturulması ve sunumunun planlanması gibi bazı hazırlıklar gerekmektedir (Aktaş ve Gündüz: 2008).

Planlı konuşmalarda yapılması gereken temel hazırlıklar ise şunlardır: Konuşmanın amacının tespiti, amaç doğrultusunda seçilen hedefe uygun malzeme, dinleyicilerin ilgisini çekecek konu başlıklarının seçilmesi, dinleyici kitlesinin durumuna, konuşma ortamına ve konuşma türüne göre konuşma üslubunun belirlenmesi, belirlenen süreyi aşmayacak bir metin hazırlama (Gündüz, 2009: 111-113). Bu hazırlıkları yapmamızın temel nedeni hazırlıklı konuşmalar bir dinleyici kitlesine karşı yapıldığı içindir. Dinleyiciler hiç tanımadığımız, düşünce ve duygularımızı nasıl karşılayacaklarını bilmediğimiz bir topluluktur. Onlar konuşmacının fikirlerini beğenip beğenmediklerini açılamadan dinlerler. Bu nedenle konuşma süresince dinleyicilerden ayrı kalmamak, söz söylerken düşünce ve duygularımızı dinleyicilere aktarmak ve fikir beraberliği sağlamak için konuşmacı ve dinleyici arasındaki mesafeyi kapamak gerekir (Şenbay, 2008: 8). Çünkü topluluk karşısında konuşmak karşllıklı konuşmaktan daha zordur. Zira konuşmacı, dinleyicilerin kendini denetlediği düşüncesine kapıldığından heyecanlanarak doğal konuşma biçimini değiştirir (Aktaş ve Gündüz: 2008: 143). Hazırlıklı konuşmanın sağlıklı olarak gerçekleşmesi ve amacına ulaşması için şu kurallar göz önünde bulundurulmalıdır:

- Her başarılı konuşmanın arkasında yoğun bir prova çalışmalarının varlığı unutulmamalı.

- Konuşmacı hazırlık aşamasında konuşma kusurlarını ve ses özelliklerini ses alma cihazından da yararlanarak belirlemeli; hatalar, yinelemelerle düzeltilmeye çalışılmalı.

- Metindeki önemli ifadelerin okunaklı olmaları sağlanmalı

- Konuşmacının kendi sesine ve üslubuna göre durak yerleri belirlenmeli.

- Topluluk karşısında yalnız bir yöne bakarak konuşulmamalı.

- Konuşma, metinden okunarak yapılmamalı.

- Konuşma, işitilebilir bir sesle yapılmalı.

- Çok hızlı konuşulmamalı.

- Gereksiz hareketlerden kaçınılmalı.

- Konuşma sürecinde kalemle, anahtarla ve ceple oynama gibi dinleyicinin dikkatini dağıtacak hareketlerden kaçınılmalı. (Gündüz, 2009: 115-116; Güneş, 2015: 172; Şenbay, 2008: 63)

Dinleyici konuşmanın hedef kitlesini oluşturduğu için konuşmacı; hedef kitlenin ilgi alanına, azlıkçokluk durumuna, kültür düzeyine, dünya görüşlerine, bağdaşık ya da bağdaşmamış oluşlarına göre konuşma planını düzenlemesi gerekmektedir (Aktaş ve Gündüz: 2008: 125). Konuşmanın amacına ulaşması için bütün bunlar göz önünde bulundurulmalıdır. Ayrıca konuşmanın en önemli ögesi olan sesin de konuşma esnasında şu özelliklere sahip olması gerekmektedir:

- İşitilebilir olması

- Boğumlanabilir olması

- Akıcı olması 
- Hoş bir ses tınısına sahip olması

- Anlaşılır olması

- Açı, net olması

- Doğal olması (Aktaş ve Gündüz, 2008: 87; İşcan, 2015: 22-24)

Hazırlıklı konuşma için belirttiğimiz bütün bu çalışmalar, konuşma esnasında gerçekleşecek olan etkileşim içindir. Etkileşim, konuşma alanında önemli ve dikkat edilmesi gereken bir boyuttur. Etkileşim sürecini konuşmacı başlatır ve yönetir. Bu nedenle konuşmacı etkileşim sürecine önem vermeli, nitelikli bir etkileşim için bazı teknikler uygulamalıdır. Öncelikle dinleyiciler hakkında bazı ön bilgiler edinmelidir: dinleyicilerin sayısı, yaşları, konumları, dinleme amaçları, kültür ve bilgi düzeyleri. Yine konuşma yeri ve alanı, görsel destekleyici kullanma durumu, süre, sunu biçimi, konferans, yuvarlak masa, panel, bilgilendirme konuşması, açık oturum gibi bilgiler konuşmacının etkileşim planlamasını kolaylaştırmaktadır (Güneş, 2014: 110). Ayrıca konuşmacının takınacağı bazı davranışlar da bu etkileşimin derecesini arttırır. Konuşmacıda bulunması gereken özellikler şunlardır:

- Ne tür bir konuşma yapılacağına bağlı olarak konuşma süresini 15 dakika ila 6o dakika arasında tutmalı, bu süreyi iyi ve doğru bir şekilde kullanmalıdır.

- Konu hakkında çok iyi bir art alan bilgisine sahip olmalı, konunun ne tür fikirlere ve içeriğe sahip olması gerektiğini bilmeli ve konuşmasını bu doğrultuda yapmalıdır.

- Doğal, rahat ve sakin bir tavırla konuşmalıdır.

- İçeriği, hedef kitlenin algılama düzeyine uygun bir şekilde yapılandırmalıdır.

- Kullanacağı görsel materyaller ile sözel anlatım arasında denge kurmalıdır.

- Konuşma türünün gerekliliklerini içeriğe göre çok iyi bir şekilde yansıtmalıdır.

- Neden-sonuç, amaç-sonuç, soru-yanıt, sav-kanıt ilişkisini gözetmelidir.

- Ana fikri konuyla çok iyi bir bağlantı kurarak geliştirmelidir.

- Konuyu destekleyici mahiyette ilginç ayrıntılar kullanmalıdır; bu ayrıntılar dinleyicilerin konuşmayı iyi anlamalarına olanak sağlayacak nitelikte olmalıdır.

- Tekrarlardan, konuyu dağıtacak sapmalardan kaçınmalıdır.

- $\quad$ Ele alacağı her bir ayrıntı ana konuyu destekleyici, açık ve tutarlı olmalıdır.

- Konun alt başlıkları arasındaki bağlantıyı özenli geçişlerle sağlamalıdır.

- Net bir bakış açısı ortaya koymalıdır; bu bakış açısını konuşma boyunca tutarlı bir şekilde sürdürmelidir.

- Görsel, işitsel, çok duyulu araçları etkin ve işlevsel bir şekilde kullanarak dinleyicilerin/ hedef kitlenin dikkatini uyanık tutmalıdır.

- Konuşmanın bütününde konuşma türü ile uyumlu bir sezgi ve duygu çeşitliliğine yön vermeli; konuşmayı, dileyicilerde/hedef kitlede duygu, bilinç ve farkındalık oluşturacak nitelikte yapılandırmalıdır.

- Uzun cümlelerden kaçınmalı; anlaşılır, kısa cümleler kurmalıdır.

- Dinleyicilerin/hedef kitlenin zihninde iz bırakacak ifadeler kullanmalıdır.

- Mümkün olduğunca teknik bir dil kullanmaktan kaçınmalı, doğal bir dil kullanmalıdır; kullanacağı diyalogların tamamı doğal etki oluşturacak nitelikte olmalıdır.

- Hedef kitlenin kültürel alt yapısına uygun kavramlar ve söz varlığı unsurları kullanmalıdır (Şengül, 2015: 243-244; Taşer, 2012). 
Konuşmacının bütün bu çabası konuşmanın amacına ulaşması için gereklidir. Konuşma öncesi yapılan hazırlıklar, konuşma sırasında uyulması gereken kurallara riayet edilmesi, konuşmanın kalitesini arttıracaktır. Bu durumdan en çok hoşnut olacak kesim de dinleyicilerdir. Zaten konuşma tek taraflı bir eylem değildir. Çünkü toplumsal ilişkilerimizde ve konuşma ortamlarında çoğu zaman ya konuşan ya da dinleyen konumunda bulunuruz (Taşer, 2012: 17). Konuşma karşllıklı gerçekleşen bir eylem, bir iletişim aracı olduğuna göre konuşanın karşısında bir veya birden fazla kişi bulunacak demektir. Başka bir deyişle konuşma eyleminde bir gönderen ve bir alıcı olması gerekir. Dinleyicisiz bir konuşma işlemi düşünülemez, dinleme gerçekleşmeden en sıradan bir konuşma işlemi dahi gerçekleşmez (İşcan, 2015: 15). Bu nedenle hazırlıklı konuşmalarda asıl amaç sadece konuşma yapmak değil dinleyiciye ulaşıp etkili bir konuşma yapmak olmalıdır. Topluluk karşısında yapılan konuşmalar sayesinde bilgi geniş kitlelerle paylaşılmaktadır. Fakat bu paylaşım sırasında yapılan konuşma kusurları konuşmanın kalitesini düşürmektedir. Genel manada konuşma kusurlarını şu şekilde sınıflandırabiliriz:

- $\quad$ Konuşma sesindeki tekdüzelik

- Boğumlama bozuklukları

- Vurgu yanlışı

- $\quad$ Ulamada dikkatsizlik

- Yersiz duraklar

- Hizlı konuşmak

- Sesi ve soluğu denetim altına alamamak

- Beden dilini yerinde ve doğru kullanamamak

- Sik sik konuşma metnine bakmak

- Gereksiz kelimeleri tekrarlama (aaa, ı11, evet, öyle, yani vb.)

- Göz teması kuramamak

- Aynı yöne, aynı kişilere bakmak

- Yerel ağızla konuşmak

- Heyecanı bastıramamak

- Kendini yetersiz görmek

- Konuşmayı gereksiz yere uzatmak

- $\quad$ Sik slk kendini övmek

- Yapmacık davranışlarda bulunmak

- Plansiz konuşmak

- Uzun süre notlara bakmak

- Konuşma süresini aşmak (Gündüz, 2009; Güneş, 2015; Gürlek ve Aksu, 2015; Şenbay, 2008; Şengül, 2015; Taşer, 2012)

Hazırlıklı konuşmada üzerinde durulması gereken fakat çok da dikkat edilmeyen nokta, konuşma sonrası değerlendirmedir. Fakat yapılan hazırlıklı konuşmaların sonu daha çok soru cevaba ayrıldığı için konuşmacı özel ortamlarda konuşmasını değerlendirememekte, yaptığı hataları dinleyicilere soramamaktadır ki bu da çok doğru bir davranış değildir. Bu nedenle farkında olunmadan yapılan her türlü konuşma kusuru konuşmacı tarafından öğrenilememekte ve bu kusurlar bir sonraki konuşmalara taşınmaktadır. Konuşmayı çekilmez hale getiren konuşma kusurlardan habersiz olan konuşmacı, zamanla istenmeyen ya da konuşmasına zorla katlanılan bir hatip durumuna düşebilmektedir. $\mathrm{Bu}$ 
aşamada topluluk karşısındaki konuşmalarda yapılan konuşma hatalarının tespiti önem arz etmektedir.

Ulusal ve uluslararası literatürde topluluk karşısında konuşma ile ilgili yapılan çalışmalarda öğretim elemanları ile ilgili doğrudan bir çalışmaya rastlanılmamıştır. Ulusal literatürde daha çok üniversite öğrencilerinin topluluk önünde konuşma ile ilgili görüşleri (Arslan, 2012), öğretmen adaylarının konuşma becerileri/kaygıları (Başaran ve Erdem, 2009; Akkaya, 2012; Sevim ve Varışoğlu, 2012; Katranc1, 2014; Mert, 2015; Temiz, 2015; İşcan ve Karagöz, 2016) ve yabancı uyruklu öğrencilerin konuşma kaygıları/becerileri (Sallabaş, 2012; Sevim, 2014; Boylu ve Çangal, 2015; Şeref ve Yılmaz, 2015; Solak ve Yılmaz 2017; Gücüyeter, Şeref ve Karadoğon, 2019) üzerine çalışmalar yer almaktadır. Uluslararası literatürde ise çalışmalar daha çok konuşma becerisinin önemi (Leong \& Ahmadi, 2017; Arbain \& Nur, 2017) ve geliştirilmesi (Tsou, 2005; Hussain, 2017; Darmuki, Andayani \& Nurkamto, 2018) üzerine yapıldığı görülmektedir.

Bu bağlamda bu çalışma, sıklıkla kitlelerin karşısına çıkan öğretim elemanlarının topluluk karşısında konuşurken yapmış oldukları hataları tespit etmeyi amaçlamaktadır. Bu amaç doğrultusunda aşağıdaki alt problemlere yanıt aranmıştır:

1. Öğretim elemanları; topluluk karşısında yapmış oldukları konuşmalarda ses, ton, vurgu, telaffuza dayalı ne tür yanlışlar yapmaktadır?

2. Öğretim elemanlarının topluluk karşısında yapmış oldukları konuşmalarda, konuşmanın şekilsel yönleri ile ilgili yanlışlar nelerdir?

3. Öğretim elemanları, konuşma esnasında ne tür teknik hatalar yapmaktadır?

\section{Yöntem}

$\mathrm{Bu}$ bölümde araştırmanın modeli, çalışma grubu, veri toplama araçları, verilerinin toplanması, veri analizi, araştırmacının rolü hakkında bilgi verilmiştir.

\section{Araştırma modeli}

Çalışmada nitel araştırma desenlerinden durum çalışması yöntemi kullanılmıştır. Nitel araştırma; gözlem, görüşme ve doküman analizi gibi nitel veri toplama yöntemlerinin kullanıldığı, olayların doğal ortamda, gerçekçi ve bütüncül bir biçimde ortaya konmasına yönelik nitel bir sürecin izlendiği araştırmadır (Yıldırım ve Şimşek, 2013: 45). Durum çalışması ise belirli duruma ilişkin sonuçlar ortaya koymak için birkaç durumun derinliğine araştırılmasıdır. Yani bir duruma dayalı ilişkin etkenler bütüncül bir yaklaşımla araştırılır ve ilgili durumu nasıl etkiledikleri ve ilgili durumdan nasıl etkilendikleri üzerine odaklanılır (Creswell, 2013: 97; Yıldırım ve Şimşek, 2013: 77). Çalışmada öğretim elemanlarının topluluk karşısında konuşma becerilerini dinleyici gözünden derinlemesine değerlendirilmesi söz konusu olduğu için bu yöntem kullanılmıştır.

\section{Çalışma grubu}

Araştırmanın yürütüldüğü süreçte (2019 yılının Şubat-Mayıs ve Eylül-Aralık ayaları aralığı) Türkiye'de bir üniversitede gerçekleştirilen konferans, sempozyum, panel, forum gibi hazırlıklı konuşmalara 
katılan öğretim elemanları tarafindan oluşturulmuştur. Bu etkinliklere 10 profesör, 3 doçent, 4 doktor öğretim üyesi katılmıştır. Katılımcıların tamamı Türk olup hepsinin anadilleri Türkçedir.

\section{Veri toplama araçlarI}

Çalışmanın verilerinin toplanmasında yapılandırılmamış gözlem formu kullanılmıştır. Gözlem formunun hazırlanmasında literatür taraması yapılmış (Akkaya, 2012; Arslan ve Sevim, 2015; Başaran ve Erdem, 2009; Erdem, 2013; Gürlek ve Aksu, 2015; Şahin ve Varışoğlu, 2015; Yıldız, 2015) ve araştırmacı tarafından ilgili çalışmalardaki bulgular referans alınmıştır. Bu doğrultuda, verilerin toplanması bölümünde belirtilen başlıklar oluşturulmuştur. Araştırmacının dinlediği hazırlıklı konuşmalardaki konuşma kusurları hazırlanan forma göre rapor edilmiştir.

\section{Verilerin toplanması}

Bu çalışma kapsamında araştırmacı, konferans, sempozyum, panel, forumlara aktif olarak katılmış ve bu konuşmaların tamamını izlemiştir. Bu süreçte; /ses, ton, vurgu, telaffuz yanlışları/, /konuşmanın şekilsel yönleri ile ilgili yanlışlar/, /konuşma esnasında yapılan teknik hatalar ve konuşmacıya dayalı yanlışlar/ başlıklarından oluşan çerçeve doğrultusunda veriler toplanmıştır. Etkinliklerde yapılan konuşmalar, araştırmacı tarafından kayıt altına alınmıştır. Yapılan kayıtlar araştırmacı tarafından tekrar kontrol edilmiş ve belirlenen başlıklara uygun olup olmadığına bakılmıştır.

\section{Veri analizi}

Çalışmada elde edilen verilerin analizinde betimsel analiz yöntemi kullanılmıştır. Betimsel analizde bir çerçeve oluşturulur. Tematik çerçeveye göre veriler işlenir. Elde edilen bulgular tanımlanır ve yorumlanır (Altunışık vd. , 2010: 322). Bu kapsamda ilk olarak gözlemler araştırmacı tarafindan kodlanmıştır. Ardından yapılan kodlamalar kamera kayıtlarının verileri ile kontrol edilmiş ve uygun olup olmadıkları belirlenmiştir. Yapılan kontrolde ilk yapılan kodlamaların ikisi hariç diğerlerinin uygun olduğu tespit edilmiştir. Uygun olmadığı belirlenen iki kodlamadan ilkinde konuşmacının yavaş konuştuğu rapor edilmiş ancak kamera kaydından tamamı izlendiğinde konuşmacının normal hızda konuştuğu saptanmıştır. Bu nedenle ilgili katılımcı için bu kod çıkarılmıştır. İkinci kodda ise eee'leme refleksi rapor edilmiş ancak kamera kaydında ilerleyen bölümlerde bir daha bunun yapılmadığı belirlenmiş bu nedenle konuşma kusuru olarak değerlendirilmemiştir. Bu çalışma kapsamında konuşmacıların sıklıkla yaptığı veya konuşma esnasında alışkanlık haline getirdiği hatalar konuşma kusuru olarak alınmıştır.

\section{Araştırmacı rolü}

Nitel araştırmalarda araştırmacı, nicel araştırmalardaki gibi belirli yöntemlere göre dışarıdan araştırma konusunu gözleyen, konuyla ilgili veriler toplayan ve verilerle analizler elde edip sunan kişi değildir. Nitel araştırmacı, alanda çalışan, araştırma kapsamındaki kişilerle görüşen ve ihtiyaç doğrultusunda bu kişilerin deneyimlerini yaşayan ve bu şekilde elde ettiği kazanımları verilerin analizinde kullanan kişidir. Veri kaynaklarıyla kurduğu bağ, ilgili bireylerle konuşma, gözlemleme, dokümanları inceleme ve konuyu anlama nitel araştırmalarda oldukça önemli yere sahiptir. Bundan dolayı nitel araştırmada araştırmacı, araştırmanın doğal bir parçası durumundadır ve veri toplama aracı işlevini yerine getirir (Yıldırım ve Şimşek, 2013: 49). Araştırmacı çalışmada katılımcı olmadığı gözlem tekniği kullanmıştır. Bu teknikte gözlemci dışarıdan herhangi bir etkide bulunmadan gözlemi 
yapar (Büyüköztürk, Kılıç-Çakmak, Akgün, Karadeniz ve Demirel, 2008). Bu bağlamda çalışmada araştırmacı, yapılan konuşmalara bir dinleyici olarak katılmış ve herhangi bir şekilde müdahil olmamıştır.

\section{Bulgular ve tartışma}

\section{Alt probleme ilişkin bulgular}

Araştırmanın birinci alt problemi "Öğretim elemanları; topluluk karşısında yapmış oldukları konuşmalarda ses, ton, vurgu, telaffuza dayalı ne tür yanlışlar yapmaktadır?” şeklinde olup bu alt probleme ilişkin bulgular aşağıda verilmiştir.

Öğretim elemanlarının ses, ton, vurgu ve telaffuzdan kaynaklanan konuşma sorunlarına ilişkin başlık; vurgu-tonlama yanlışlı̆̆ı, hızlı konuşma, yavaş konuşma, yerel ağız özellikleriyle konuşma, nefesini ayarlayamama, telaffuz hataları, sesin titremesi olarak kodlanmıştır.

Bu kodlamalar doğrultusunda öğretim elemanlarının bu bölümde en yoğun olarak yapmış olduğu konuşma kusuru vurgu-tonlama yanlışı ile hızlı konuşma olmuştur. Özellikle vurgulu söyleyiş, sesin anlaşılabilirliğini doğrudan etkiler. Vurgu, konuşmanın doğru anlaşılması için çok önemlidir. Bu eksiklik, dinleyiciler tarafından konuşmaların bütünüyle anlamlı olarak işitilmediğini de gösterir. Anlaşlmadan dinleme, dinleyicileri olumsuz etkiler. (Gürlek ve Aksu, 2015: 213). Dinleme olmadan iletişim tam olarak gerçekleşemeyecektir. İletişimde istenilen sonuçlara ulaşılması için konuşan ve dinleyen arasındaki ilişki bağı kesintiye uğramamalıdır. Konuşmacı amacına ulaşmak için bu bağı korumalıdır (İşçan, 2015: 15).

Bu başlık altında yapılan ikinci en yoğun kusur, konuşma hızıyla ilgilidir. Özellikle topluluk önünde yapılan konuşmalar belirli bir süre içinde yapılmaktadır. Bu yüzden konuşmacılar belirli süre içinde yapılması gereken konuşmalar için eğer daha önce bir süre ayarlama hazırlı̆̆ yapmamış ise konu hızlı anlatılmaktadır. Olağan konuşmalarda konuşma hızı (tempo) dakikada 125-175 kelime arasında değişir. Bu kelimelerin altına düşen konuşma yavaş bunun altındakiler ise hızlı konuşma kabul edilir (İşcan: 2015: 64; Taşer, 2012: 134).

Etkili bir konuşma belirli bir ritim ve hıza sahip olmalıdır. Konuşmacı dinleyenlerin anlama bakımından sınırıklarını dikkate almak durumundadır. Gereğinden hızlı ya da yavaş konuşma, dinleyiciler üzerinde istenen etkiyi oluşturmaz. Hatta konuşmanın takip edilememesine yol açar. Bu bakımdan konuşmacı konuşma hızını; konusuna, hitap ettiği kitleye göre ayarlamalıdır (Calp ve Calp, 2016: 119). Konuşma hızının dakika ile kelime sayısı oranı şu şekilde olmalıdır:

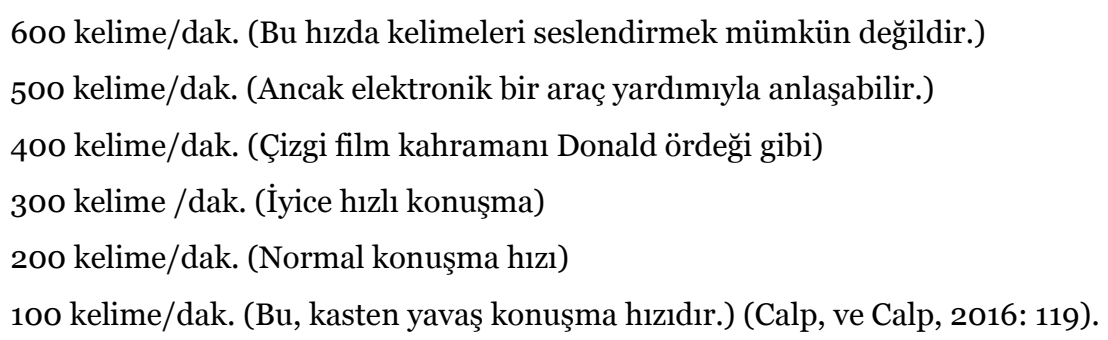

Bu başlık altında tespit edilen son kusur yerel ağız özelliğine göre konuşmadır. 17 konuşmacının sadece birinde yerel ağız özelliğine göre konuşma görülmüştür. Bir dilin bölgeler arasında söyleyiş 
farklılıkları olabilir. Dinleyici anlamını bilmediği kelimeleri, fark etmediği ses ve eklerle yapılan konuşmayı algılamakta zorlanır (Gürlek ve Aksu, 2015: 211). Özellikle farklı bölgelerden gelen öğrencilerin bulunduğu üniversitelerde yapılacak konuşmalarda bu hususa dikkat edilmesi gerekmektedir.

Öğretim elemanlarının topluluk karşısında yapmış oldukları konuşmalarda ses, ton, vurgu, telaffuza dayalı yanlışların mahiyetine dair başlık altında kodlanan; nefesini ayarlayamama, telaffuz hataları, sesin titremesi gibi kusurlara rastlanılmamıştır.

\section{Alt probleme ilişkin bulgular}

Araştırmanın ikinci alt problemi "Öğretim elemanlarının topluluk karşısında yapmış oldukları konuşmalarda konuşmanın şekilsel yönleri ile ilgili yanlışlar nelerdir?” şeklinde olup bu alt probleme ilişkin bulgular aşağıda verilmiştir.

Öğretim elemanlarının topluluk karşısında yapmış oldukları konuşmalarda konuşmanın şekilsel yönlerine dair başlık; konuşma akışını sağlayamama, konuşma süresini ayarlayamama konu dışına çıkma, konuşma planına uymama şeklinde kodlanmıştır.

Bu kodlamalarda en fazla karşlaş̧lan sorun konuşma süresini ayarlayamamadır. 17 konuşmacından 10’u konuşma süresini ayarlayamama problemi yaşamıştır. Diğer kodlamalara dair kusurların temelinde bu problem yatmaktadır. Konuşma metninin içeriği ne kadar dolu olursa olsun eğer konuşmacı, konuşma süresini aşarsa konuşma akışını sağlayamazsa, bu durum dinleyiciler nazarında hoşnutsuzluk ortaya çıkarır. Hoşnutsuzluğun temel nedeni, dinleyicilerin dikkatlerinin dağılmasından kaynaklanmaktadır.

Konuşmada etkili ve başarılı olabilmek, dinleyenlerin dikkati ile doğru orantılıdır. Dinleyenlerin dikkatini uyandırmak, diri tutmak ve sürdürmek, konuşana düşer. Bunun için de konuşan kişi bütün çabasını bu noktaya yöneltmek zorundadır. Bir dinleyici, dikkatini uzun süre aynı konu üzerinde yoğunlaştırıp sürdüremez. Çünkü dikkat, bir şeyden başka bir şeye saniyenin beşte birinde geçmekte, yönelivermektedir (Taşer, 2012: 94). Bu nedenle konuşmacılar konuşma sürelerini artırarak daha fazla bilgi verme düşüncesinden kaçınmalıdırlar. Çünkü dinleme edimi kolay gerçekleşmemektedir.

Dinleme; ses, müzik, gürültü, konuşma gibi sesli uyarıcıları işitmek, anlamak ve zihinde yapılandırmak için kulak ve beynimizde yürütülen karmaşık bir süreçtir. Dinleme sadece sesleri doğru işitme işlemi değil işitmenin ötesindeki işlemleri, yani işitilenleri anlamak için gerekli zihinsel işlemleri de kapsamaktadır (Güneş, 2014: 79). Bu yüzden konuşmanın amacına ulaşabilmesi için dinlemenin tam olarak gerçekleşmesi gerekir. İletişim açısından konuşmacı ile dinleyicinin birbiriyle bağlantılı olduğu başarılı bir konuşma, konuşan ile dinleyici arasındaki iletişimin kesintisiz ve uyum içinde devam etmesiyle gerçekleşir. Çünkü konuşma sırasında konuşmacı ile dinleyiciler karşılıklı iletişim halinde bulunurlar (Aktaş ve Gündüz: 2008: 87). Bu karşllıklı iletişimin sağlıklı sürdürülmesi, bilginin aktarılması için önem arz etmektedir.

Bu alt başlık altında diğer bir yoğun konuşma kusuru da konuşma akışını sağlayamama olmuştur. Konuşmada akıcılı̆̆ın bozulması konuşma kusurlarında sıklıkla görülür (Özgür, 2003). Bunun temel nedeni, yapılacak konuşmanın aşamalarının önceden tespit edilmemesidir. Bu durum, konuşma amacından saptıkça konuşmacının kaçamayacağı bir olaydır. Bir konu ne kadar iyi bilinirse bilinsin düşünceler düzene konmadan sunuşa başlandığında konun akışı gerçekleşememektir (Şengül, 2015). 
Konu dışına çıkma ve konuşma planına uymama gibi kusurlar, topluluk karşısında yapılan bir konuşmanın etki derecesinin azalmasına neden olmaktadır.

\section{Alt probleme ilişkin bulgular}

Araştırmanın üçüncü alt problemi "Öğretim elemanları, konuşma esnasında ne tür teknik hatalar yapmaktadırlar?” şeklinde olup bu alt probleme ilişkin bulgular aşağıda verilmiştir.

Öğretim elemanlarının konuşma esnasında yaptıkları teknik hatalar; kâğıda bağlı kalma/ konuya hâkim olamama/ mekânı kullanamama/ beden dilini kullanamama/ arkadaşlar, yani, şey, şimdi, boşver gibi kelimeleri tekrarlama, 1111, eee gibi sesleri tekrarlama/ argo kullanma, şeklinde kodlanmıştır.

Bu kodlamalara göre konuşma esnasında en fazla yapılan teknik hatalar; kâğıda bağlı kalma ve bu davranışın sebep olduğu dinleyicilerle göz teması kuramama, konuşmayı tek bir yöne bakarak yapma olmuştur. Konuşmayı etkili kılan temel esaslardan biri konuşma esnasında dinleyiciye, muhataba, bakma davranışıdır. Dinleyici kendisinin dikkate alındığını, ancak konuşmacı ile göz teması kurduğunda hisseder. Ĕger konuşmacı konuşma metninden gözünü ayırmadığı takdirde dinleyicilerle göz teması da kuramayacaktır. Özellikle konuşmacılar, dinleyicilerle konuşma eylemi yerine, onlara verilen süre içerisinde, okuma eylemi içerisine girerlerse bu durum konuşmanın etki derecesini azaltacaktır. Dinleyenlerle doğru bir diyalog kuramayan konuşmacı başarısız olur. Konuşmacının başarısızlığı, yeterli ve etkili bir dinleme faaliyetinin gerçekleşmediğini göstermektedir (Çiftçi, 2001: 175).

Bu başlık altında diğer bir teknik hata "mılama, eeeleme"lerdir. Kulağı tırmalayan bu konuşma kusuru; konuşmacı aradığı kelimeyi hatırına getiremediğinde zaman kazanmak için söz arasındaki boşlukları "hımm, ılı, şeyyy, eeee" gibi gereksiz seslerle doldurmasından dolayı ortaya çıkar (Yıldırım, 2020: 605). Bu ifadeler zamanla kulağı rahatsız eden bir ses haline dönüşür. Dinleyicilerin dikkatini dağıtan bir unsur oluverir.

Son olarak, hazırlıklı konuşmaların yapıldığı programlara alanına hâkim konuşmacılar davet edildiği için konuya hâkim olamama koduna rastlanılmamıştır. Fakat sadece bir konuşmacı sunumuna başlamadan önce "Bu konuda fazla bilgi sahibi olmasak da dilimiz döndüğünce verilen süre içinde sizlere bir şeyler anlatmaya çalışacağım.” ifadesi kullanmıştır. Konuşmacı bu ifadeyi kullanırken hafifçe gülümsemesi, tevazu etme olarak anlaşılmıştır. Fakat özellikle topluluk karşısında yapılacak konuşmalarda alanında uzman kişiler davet edilir. Dinleyicilere bu şekilde duyurulur. Dinleyiciler, alanında yetkin bir kişiyi dinlemek için programlara katılım sağlar. Bu nedenle konuşmacının kullandığı veya kullanacağı bu tarz tevazu ifadeleri, konuşma tekniği açısından uygun değildir.

Üçüncü alt problem kapsamında belirlenen mekânı ve beden dilini kullanamama/ arkadaşlar, yani, şey, şimdi, boş ver gibi kelimeleri tekrarlama/ argo kullanma gibi kodlamalarla sunumlarda karşlaşılmamıştır.

\section{Sonuç ve öneriler}

$\mathrm{Bu}$ çalışmada Türkiye'de bir üniversitede bahar ve güz eğitim/öğretim süresince öğretim elemanlarının (Profesör, Doçent, Dr. Öğretim Üyesi) konferans, sempozyum, panel, forum gibi programlarda yaptıkları hazırlıklı konuşmalar değerlendirilmiştir. Buna göre: 
Araştırmanın birinci alt probleminde öğretim elemanlarının topluluk karşısında yapmış oldukları konuşmalarda ses, ton, vurgu, telaffuza dayalı yanlışlar ele alınmıştır. Bu başlık altında konuşmacıların sıklıkla vurgu-tonlama ile hızlı konuşma yanlışını yaptıkları görülmüştür. Vurgu-tonlama yanlışı sesin sağlıklı işitilmemesine neden olmaktadır. Hızlı konuşma ise sağlıklı dinlemeyi aksatmaktadır. Yaman’a (2007) göre ana dilini iyi bilmek iyi konuşmanın temelidir fakat bilgi ve birikimlerini karşı tarafa iletmekte zorlanmak, o bilgileri kullanamamak anlamına gelir. Kullanılmayan bilgi ise doğal olarak işlevselliğini yitirir. Öğretim elemanlarının sahip oldukları bilgileri doğru aktarımı söyleyişe önem veren akııı bir konuşmayla sağlanacaktır (Yıldırım, 2020).

Araştırmanın ikinci alt probleminde öğretim elemanlarının topluluk karşısında yapmış oldukları konuşmaların şekilsel yönleri ile ilgili yanlışlar yorumlanmıştır. Bu bölümde konuşma akışını sağlayamama, konuşma süresini ayarlayamama, konu dışına çımma, konuşma planına uymama gibi kusurlara rastlanılmıştır. Bu tarz kusurların temelinde konuşmayla ilgili etkileşimli hareket planının oluşturulmaması vardır (Güneş, 2015; Şengül, 2015).

Araştırmanın üçüncü alt probleminde öğretim elemanlarının konuşma esnasında yaptıkları teknik hatalar bulgulanmıştır. Bu bölümde kâğıda bağlı kalma ve ınlama/eeeleme gibi iki önemli kusura rastlanmıştır. Özellikle konuşmacının, beraberinde getirdiği kâğıtlara, gereğinden fazla bakması konuşmanın kalitesini düşürmektedir. Görsel materyal ile sözel anlatım arasında denge kurulmalıdır (Paulino'dan (2006) aktaran Güneş, 2015; Şengül, 2015).

Araştırmanın bulgularına göre öne çıkan temel görüş, konuşma eyleminin kendi başına bağımsız bir eylem olmadığıdır. Sever'e (2004) göre, konuşma becerisi; okuma, dinleme ve yazma beceriyle bütünleşik bir yapıya sahiptir. Özellikle dinleme ve konuşma becerileri, birbirlerini doğrudan destekleyen, biri olmadan diğerinin varlık alanı sinırlanan iki temel beceridir (Arslan ve Sevim, 2015). $\mathrm{Bu}$ yüzden konuşmacılar sadece yapacakları konuşmaya hazırlanmamalı, birçok yönü ile dinleme edimi için de hazırlık yapmalıdır. Dinleme, en çok kullandığımız dil becerisidir (Çetinkaya, Z. C. 2011; Doğan, 2016; Sever, 2004). Dinleme; duyma, yorumlama, değerlendirme gibi tepki süreçlerinden oluşur (Gürel ve Tat, 2012: 277-278). Bu süreçlerin herhangi biri sekteye uğradığında dinleme sağlıklı bir şekilde gerçekleşmez. Dinleme sürecinde en önemli görev konuşmacıya düşmektedir (Ateş, 2018: 141). Sadece konuşma kalitesi ile ilgilenen konuşmacılar, bir iletişim edimi olan dinlemeyi önemsemediği müddetçe sağlıklı bir iletişim gerçekleştiremezler.

Araştırmanın sonuçlarına göre aşağıdakiler önerilebilir:

* Topluluk karşısında konuşma yapacak her türlü vasıftaki konuşmacı; dinleme ediminin kurallarını, konuşma kurallarını bildiği kadar bilmelidir.

* Mutlak suretle konuşma süresince dinleyicilerle göz teması kurulmalı ve konuşma bitene kadar bu temas sürdürülmelidir.

* Konuşma yapmadan önce konuşma hazırlığı yapılmalıdır.

* Süreli konuşmalarda verilen süreye uyulmalıdır. 


\section{Kaynakça}

Akkaya, A. (2012). Öğretmen Adaylarının Konuşma Sorunlarına İlişkin Görüşleri. Mustafa Kemal Üniversitesi Sosyal Bilimler Enstitüsü Dergisi, 9. (20), 405-420.

Aktaş, Ş. ve Gündüz, O. (2008). Yazılı ve Sözlü Anlatım. Ankara: Akçağ Yayınları.

Altunışık, R. , Coşkun, R., Yıldırım, E. ve Bayraktaroğlu, S. (2010). Sosyal Bilimlerde Araştırma Yöntemleri. 6. Baskı. Sakarya: Sakarya Kitabevi.

Arbain \& Nur, D. M. (2017). Techniques for Teaching Speaking Skill in Widya Gama Mahakam University. Script Journal: Journal of Linguistic and English Teaching, P-ISSN: 2477-1880; EISSN: 2502-6623, 2-1, 14-25.

Arslan, A. (2012). Üniversite öğrencilerinin "topluluk karşısında konuşma" ile ilgili çeşitli görüşleri (Ağrl İbrahim Çeçen Üniversitesi Örneği). Turkish Studies, 7/3, 221-231.

Arslan A. ve Sevim, O. (2015). Konuşama Becerisinin Geliştirilmesinde Kullanılabilecek Etkinlik Önekleri. A. Şahin (Ed.), Konuşma Eğitimi Yöntemler-Etkinlikler (178-205). Ankara: Pegem Akademi.

Ateş, M. (2018). Ortaokul Öğrencilerinin Dinleme Kaygılarının İncelenmesi. 21. Yüzyılda Eğitim ve Toplum Dergisi, 7. (19), 139-153.

Başaran, M ve Erdem, İ. (2009). Öğretmen Adaylarının Güzel Konuşma Becerisi İle İlgili Görüşleri Üzerine Bir Araştırma. Kastamonu Eğitim Dergisi, 17. (3), 743-754.

Boylu, E. ve Çangal, Ö. (2015). Yabancı dil olarak Türkçe öğrenen Bosna-Hersekli öğrencilerin konuşma kaygılarının çeşitli değișkenler açısından incelenmesi. Uluslararası Türkçe Edebiyat Kültür Eğitim (TEKE) Dergisi, 4 (1), 349-368.

Büyüköztürk, Ş., Kılıç-Çakmak, E., Akgün, Ö. E., Karadeniz, Ş. ve Demirel, F. (2008). Bilimsel Araştırma Yöntemleri. Ankara: Pegem Akademi Yayıncılık.

Calp, M. ve Calp, Ş., (2016). Özel Öğretim Alanı Olarak Türkçe Öğretimi I-II. Ankara: Nobel Akademik yayıncılık.

Creswell, J. W. (2013). Nitel Araştırma Yöntemleri. (Bütün, M. ve Demir S. B. Çev.) Ankara: Siyasal Yayın Dağıtım.

Çetinkaya, Z. C. (2011). Kişilerarası İletişimde Dinleme Becerisi. Ankara: Nobel Akademik Yayıncılık.

Çiftçi, M. (2001). Dinleme Eğitimi ve Dinlemeyi Etkileyen Faktörler. Afyon Kocatepe Üniversitesi Sosyal Bilimler Dergisi, 2. (1), 164-175.

Darmuki, A., Andayani, Nurkamto, J. \& Saddhono, K. (2018). The Development and Evaluation of Speaking Learning Model by Cooperative Approach. International Journal of Instruction, eISSN: 1308-1470, 11-2, 115-128.

Doğan, Y. (2016). Dinleme Eğitimi. Ankara: Pegem Akademi.

Erdem, İ. (2013). Konuşma Eğitimi Esnasında Karşılaşılan Konuşma Bozuklukları ve Bunları Düzeltme Yolları. Adıyaman Üniversitesi Sosyal Bilimler Enstitüsü Dergisi Türkçenin Eğitimi Öğretimi Özel Sayısı, 6. (11), 415-452.

Gücüyeter, B., Şeref, İ., Karadoğan, A. (2019). Tutor Destekli Öğretim Modeli’nin Yabancı Öğrencilerin Türkçe Konuşma Becerilerine ve Kaygı Düzeylerine Etkisi. Atatürk Üniversitesi, Türkiye Araştırmaları Enstitüsü Dergisi, 64, 535-552.

Gündüz, O. (2009). Konuşma Eğitimi. Ahmet Kırkkılıç ve Hayati Akyol. (Editörler). İlköğretimde Türkçe Öğretimi (93-133). Ankara: Pegem Akademi.

Güneş, F. (2007). Türkçe Öğretimi ve Zihinsel Yapılandırma. Ankara: Nobel Yayıncılık.

Güneş, F. (2014). Türkçe Öğretimi, Yaklaşımlar ve Modeller. Ankara: Pegem Yayınları

Güneş, F. (2015). Konuşma Öğretiminde Uygulanan Yaklaşım ve Modeller. A. Şahin (Ed.), Konuşma Ĕ̆itimi Yöntemler-Etkinlikler (151-175). Ankara: Pegem Akademi. 
Gürel, E. ve Tat, M. (2012). Bir İletişim Edimi ve Türkçede Bulunan Dinleme Temalı Atasözleri ile Deyimler Üzerine Bir İçerik Analizi. Uluslararası Sosyal araştırmalar Dergisi, 5. (23), 276-297.

Gürlek, M. ve Aksu, E. (2015). Konuşma Hataları. A. Şahin (Ed.), Konuşma Eğitimi YöntemlerEtkinlikler (209-223). Ankara: Pegem Akademi.

Hussain, S. (2017). Teaching Speaking Skills in Communication Classroom. International Journal of Media, Journalism and Mass Communications, 3-3, 14-21.

İşcan, A. (2015). İletişim, Konuşma ve Konuşmayla İlgili Temel Kavramlar. A. Şahin (Ed.), Konuşma Ĕ̆itimi Yöntemler-Etkinlikler (1-25). Ankara: Pegem Akademi.

İşcan, A. ve Karagöz, B. (2016). Türkçe Öğretmeni Adaylarının Konuşma Kaygılarının İncelenmesi (Gaziosmanpaşa Üniversitesi Örneği). Ahi Evran Üniversitesi Kırşehir Eğitim Fakültesi Dergisi (KEFAD), 17-3, 193-206.

Katrancı, M. (2014). Öğretmen adaylarının konuşma becerisine yönelik öz yeterlik algıları. Bartın Üniversitesi Eğitim Fakültesi Dergisi, 3/2, 174-195.

Leong, L.-M. \& Ahmadi, S. M. (2017). An Analysis of Factors Influencing Learners' English Speaking Skill. International Journal of Research in English Education. DOI: 10.18869/acadpub.ijree. 3441.

Mert, E. L. (2015). Türkçe öğretmen adaylarının konuşma kaygılarına ilişkin birinceleme. Uluslararası Sosyal Araştırmalar Dergisi, 8/37, 784-789.

Özgür, İ. (2003). Konuşma bozuklukları ve sağaltımı. Adana: Nobel Yayınevi

Paulino, E. (2006). Abc de l'expose et l'expression Orale, BCE - Université de Neuchâtel.

Sallabaş, M. E. (2012). Türkçeyi yabancı dil olarak öğrenenlerin konuşma kaygılarının değerlendirilmesi. Turkish Studies, 7 (3), 2199-2218.

Sever, S. (2004). Türkçe Öğretimi ve Tam Öğrenme. Ankara: Anı Yayıncılık.

Sevim, O. (2014). Yabancı uyruklu öğrencilerin Türkçe konuşma kaygılarının bazı değişkenler açısından incelenmesi. EKEV Akademi Dergisi, 18 (60), 389-402.

Sevim, O. ve Varışoğlu, B. (2012). Öğretmen adaylarının temel dil becerilerinde yaşanan sorunlarla ilgili düşünceleri: Atatürk Üniversitesi örneği. Gaziantep University Journal of Social Sciences, 11(4), 1042-1057.

Solak, E. M. ve Yllmaz, F. (2017). Türkçe öğrenen yabancı uyruklu öğrencilerin konuşma kaygısı nedenleri ve düzeyleri. Eğitim ve Öğretim Araştırmaları Dergisi, 6-1, 2146-9199.

Şahin, A. ve Aydın, G. (2015). Konuşmada Beden Dili. A. Şahin (Ed.), Konuşma Eğitimi YöntemlerEtkinlikler (226-234). Ankara: Pegem Akademi.

Şahin Yağmur, E. ve Varışoğlu, B. (2015). Konuşma Türleri ve Konuşmada Nezaket Kuralları. A. Şahin (Ed.), Konuşma Ĕ̆itimi Yöntemler-Etkinlikler (120-144). Ankara: Pegem Akademi.

Şenbay, N. (2008). Söz ve Diksiyon Sanatı. İstanbul: Yapı Kredi Yayınları.

Şengül, M. (2015). Konuşma Metin ve Konuşma Materyalleri Hazırlama. A. Şahin (Ed.), Konuşma Ĕ̆itimi Yöntemler-Etkinlikler (235-254). Ankara: Pegem Akademi.

Şeref, İ., Yllmaz, İ. (2015). Yemenli Öğrencilerin Türkçe Yazma ve Konuşma Becerilerinin Geliştirilmesinde Karikatür Kullanımına Yönelik Bir Uygulama, Turkish Studies, 10/7, 835-860.

Taşer, S. (2012). Konuşma Eğitimi. İstanbul: Pegasus Yayınları.

Temiz, E. (2015). Pedagojik Formasyon Alan Öğretmen Adaylarının Konuşma Kaygıları, Turkish Studies, 10/3, 985-992.

Temizyürek, F., Erdem, İ ve Temizkan, M. (2016). Konuşma Eğitimi Sözlü Anlatım. Ankara: Pegem Yayınları. 
Tsou, W. (2005). Improving the Speaking Skill through Instruction about Oral Classroom Participation. Foreıgn Language Annals, 38-1, 46-55.

Ünalan, Ş. (1999). Yeni Gelişmeler Işığında Türkçe Öğretimi. Ankara: Gazi Üniversitesi İletişim Fakültesi Yayınevi.

Yaman, E. (2007). Konuşma sanatı. ( 4. Baskı). Ankara: Gazi Kitabevi.

Yıldırım, A. \& Şimşek, H. (2013). Sosyal Bilimlerde Nitel Araştırma Yöntemleri. Ankara: Seçkin Yayınları.

Yıldırım, N. (2020). Öğretmen Görüşlerine Göre Ortaokul Öğrencilerinin Konuşma Kusurları. Ana Dili Eğitimi Dergisi, 8. (2), 597-610.

Yıldız, D. (2015). Yönetici ve Öğretmen Görüşlerine Göre Maarif Müfettişlerinin Konuşma Becerilerinin Değerlendirilmesi. Mustafa Kemal Üniversitesi Sosyal Bilimler Enstitüsü Dergisi, 12. (31), 1-20. 